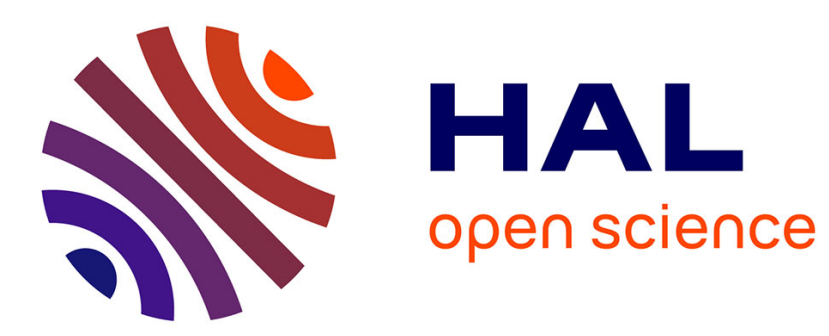

\title{
Will we pay the same way? Empirical evidence of payment behaviours convergence on EMU panel data
}

Sandra Deungoue

\section{To cite this version:}

Sandra Deungoue. Will we pay the same way? Empirical evidence of payment behaviours convergence on EMU panel data. 2005. halshs-00180089

\section{HAL Id: halshs-00180089 \\ https://shs.hal.science/halshs-00180089}

Submitted on 17 Oct 2007

HAL is a multi-disciplinary open access archive for the deposit and dissemination of scientific research documents, whether they are published or not. The documents may come from teaching and research institutions in France or abroad, or from public or private research centers.
L'archive ouverte pluridisciplinaire HAL, est destinée au dépôt et à la diffusion de documents scientifiques de niveau recherche, publiés ou non, émanant des établissements d'enseignement et de recherche français ou étrangers, des laboratoires publics ou privés. 
W.P. 05-01

\section{Will we pay in the same way ? Empirical evidence of payment behaviours convergence on EMU panel data}

\section{Sandra DEUNGOUE}

Mars 2005

GATE Groupe d'Analyse et de Théorie Économique

UMR 5824 du CNRS

93 chemin des Mouilles - 69130 Écully - France

B.P. 167 - 69131 Écully Cedex

Tél. +33 (0)4 72866060 - Fax +33 (0)4 72866090

Messagerie électronique gate@gate.cnrs.fr

Serveur Web : www.gate.cnrs.fr 


\title{
WILL WE PAY IN THE SAME WAY? \\ EMPIRICAL EVIDENCE OF PAYMENT BEHAVIOURS CONVERGENCE ON EMU PANEL DATA
}

\author{
Sandra Deungoue
}

\begin{abstract}
The purpose of this study is to analyze the observed changes in payment behaviours by underlining the influence of factors such as financial opening, regulations and technological innovation. We show how forces acting in order to mould the national retail banking markets into a Single Payment Area (SPA) within the European Monetary Union (EMU) have impacted the payment instruments demand. We analyse the integration process and measure the importance of its major steps by testing the convergence of payment behaviours. We develop a model of conditional convergence concerning the use of five payment instruments: cash, card, cheque, credit transfer, and direct debit. The tests of conditional convergence are carried out using the techniques of instrumental variables on annual panel data in EMU. The results demonstrate that convergence occurs on demand for all payment methods except cheque.
\end{abstract}

JEL classification : D12, F36

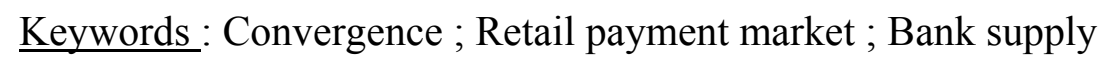

\section{RESUME}

Le but de cette étude est d'analyser les changements des habitudes de paiement en mettant l'accent sur l'influence de facteurs tels que l'ouverture financière, la reglementation et l'innovation technologique. Nous montrons comment les mesures prises dans le but de construire un Espace Unique de Paiement en Euros ont affectées l'utilisation des instruments de paiement. Nous analysons le processus d'intégration et mesurons l'importance de ses principales étapes en examinant la convergence des comportements de paiement relatifs à cinq moyens de paiement : les espèces, la carte, le chèque, le virement et le débit direct. Nous développons un modèle de convergence conditionnelle sur données de panel. Les résultats font ressortir un mouvement de convergence de la demande relative à tous les instruments de paiement exception faite du chèque.

Classification JEL : D12, F36

Mots clés: Convergence; Marché européen des paiements de détail; Offre des services bancaire

I am grateful for the helpful comments and suggestions given by Pr. Jean-François Goux, Dr. Sheri Markose, Dr. Dominique Chabert and Dr. Yiing Jia Loke. Any remaining errors are my own responsibility. 


\section{INTRODUCTION}

Payment habits develop within a specific legal, financial and technological context. Any modification of the characteristics of this environment is likely to involve changes in payment behaviours. Over the last two decades, significant changes of payment instrument use were observed. According to studies undertaken by Snellman and al (2001), and Markose and Loke (2000; 2002), these changes were, for the most part, a result of technological innovation. Other authors, such as Guariglia and Loke (2004), whom will hereafter be referred to as GL, have developed empirical studies combining the technological factors with socio-macroeconomic factors. However, although many authors, including Snellman (2000) agree that the legislative environment and banking integration are factors that have an influence on payment behaviours, no empirical study has focused on this issue. Only Humphrey, Pulley and Vesala (1996), hereafter HPV, have integrated some institutional factors such as the banking concentration into their study.

The novelty and originality of our approach lies in the introduction of regulations and financial opening as potential explanatory variables of changes in demand for payment instruments. We presume that modifications of payment behaviours observed in the European Monetary Union (EMU) are as a result of at the same time the unification of national markets for retail payments through the Single Payment Area (SPA), and the changes of the technological and socio-macroeconomic factors. In fact, the development of a comprehensive and effective legal framework for retail payments undertaken by the European Commission and the integration of payment structures carried out by the banking associations are likely to harmonize banking practices and to lead to the convergence of payments behaviours. In fact, the more open the payment market of an economy is, the more its regulations are harmonised with international practices, the more this country can imitate and implement foreign payment technologies and habits. The purpose of this study is thus to determine the degree of this convergence process by highlighting the influences of financial opening, banking integration and harmonisation of regulations in the European Union. 
Another contribution of our paper is the use of the techniques for dynamic panel data models, using instrumental variables estimators within the framework of the generalized method of moments (GMM). In addition, in order to address the issue of substitution, we consider that the demands for competitive payment instrument are predetermined variables as opposed to strictly exogenous ones. Furthermore, unlike the previous papers, we study $\operatorname{cash}^{1}$ use and the demand for cashless instruments simultaneously.

The structure of the paper is as follows. In the next section, we present some features of regulations and prices that have been on the European payment instruments market since 1990. Then, in Section 3, we present the methodological approach of our model. In Section 4 we carry out the convergence tests; and finally we conclude in the last section.

\section{The Single Payment Area}

The SPA is one domestic euro payment area grouping together the fifteen existing national areas, and in which payments are carried out with identical time and costs. Its construction is a major issue, which is currently the principal subject of several debates between consumers, bank industry groups and European institutions. The objective of this SPA is to allow customers to complete payment transactions of any size as securely and efficiently as they presently do at national level. The introduction of the euro banknotes and coins into circulation in 2002 has been the occasion to give a progress report on a harmonized SPA and to formulate suggestions as to how its achievement might be accelerated. This report shows that the single currency has, to date, failed to provide the benefits expected from the elimination of exchange rate risks and the reduction in currency conversion costs within the euro area. Indeed, cross-border retail payments still take longer and cost more than domestic payments. While national retail payments systems are efficient, customers continue to face several obstacles for getting financial services elsewhere in the EU outside their country of residence.

The persistence of barriers is due as much to legislative differences as to heterogeneous payment systems. These differences come from the independent

\footnotetext{
${ }^{1}$ The term "cash" refers to government supplied notes and coins
} 
creations of national financial systems. In each country, national systems have developed in a specific lawful context and at different speeds. However, the creation of a SPA requires a harmonization, or at least an adaptation of these various national legislations. Today, only card payments have international functionality and seamless system integration; no other payment method provides a satisfactory level of service for cross-border payments.

Since 1990, many attempts in the form of both legal actions (regulations, directives and recommendations) and banking agreements have been made to remove these barriers. The banking associations created the European Payment Council, (EPC), whose purpose is to accelerate the setting up of the Single Euro Payment Area $(\mathrm{SEPA})^{2}$, by providing guidance to the banking industry. The European Commission, for its part, decided to establish a common legal framework for payments in order to improve the completion of the SPA. For the most part, these measurements focused on two points. On the one hand, to allow the credit institutions to offer their services in an identical way inside the Internal Market, by eliminating "the border effect". On the other hand, to give consumers the possibility of having payment services across the European Union with a quality-to-price ratio equivalent to the national payments.

However, the achievement of the SPA will depend equally on the willingness of customers to accept changes. Both consumers and credit institutions are expected to adopt two behaviours:

First of all, the consumers must check out information about the prices of the payment services that their bank and competing banks are offering. In actual fact, with the free circulation of capital in the single market and the financial liberalisation worldwide, transparency is the sine qua non condition for the intensification of competition. Nowadays, competition in the banking sector is reduced because few consumers switch banks. As a result, there is little incentive for credit institutions to concern themselves with the fall of the prices.

Secondly, it is necessary that banks review their marketing policies in order to adapt them to the desired level of competition. Today, retail payments services are still strongly dependant on domestic considerations. European competition is increasing slightly and the single retail payments market is embryonic in its demand.

\footnotetext{
${ }^{2}$ The banking associations concentrate exclusively on the countries that use euro (Single Euro Payment Area), while the Commission constructs a Single Payment Area with the geographical scope of the internal market
} 
The internationalized banks in the internal market align their strategy with domestic supplies without checking out the meaningful points of differentiation required to create a competitive advantage. For instance, in France, foreign banks do not offer interest-bearing current accounts because they do not want to break with the French tradition of "ni-ni" (i.e. no interest on current accounts and no cheque handling fees). In addition, banks are also expected to improve the transparency of payment services prices in order to enhance the mobility in the single market and to strengthen the competition for industry. The combination of an easier comparison from suppliers and increasing competition will bring down the highest prices in the SPA and reduce the differences in the service charges and quality.

Our study is motivated by the inquiries made by the European Commission concerning the changes it has to bring to the management of means of payment. The communication of a "New Legal Framework for Payments in the Internal Market" raised many debates, in particular with regard to the consequences of the regulation both on the use of a payment instrument and on the relationships between banks and their customers. It was mainly a question of distinguishing the aspects of the payment transactions that should be regulated from those that should be left to contractual freedom and to the self-regulation system of the market. If we take the case of value dates, for instance, the diversity of laws and regulations that exists across the EU requires a minimal harmonization. Various opposing opinions are put forward to explain this. On the one hand there are those who think that value dates are related to the marketing policies of banks and that therefore regulation must focus only on demands for greater transparency. On the other hand there are those who estimate that settlement time is only one of many points that should be governed by regulation. Another point which is worth discussing relates to payment methods coming from the New Information And Communication Technologies (NICT). A case in point here is the fact that payments made via mobile phones lead to divergent interpretations of the nature of pre-paid mobile phone cards. While some countries consider that mobile phone operators are not financial services providers, other Member States, perceive prepaid phone cards as being a form of electronic money when they are used to purchase products and services other than traditional communications (ring tones,

\footnotetext{
${ }^{3}$ http://europa.eu.int/comm/internal_market/payments/framework/2004-contributions_en.htm\#summaries
} 
news, drinks, etc) and believe, therefore, that they too should be subject to the rules applying to electronic money. Yet, a smoothly functioning financial system involves that all these various aspects of payment services correspond to existing and common regulations. Consequently, the realization of the SPA requires that one installs a homogeneous legal framework governing the integration of the national retail payments markets.

The purpose of our study is not so much to determine what the consequences of a specific regulation on the use of payment instruments are, as to emphasize the fact that a single regulation can lead to the convergence of payment behaviours and thus explain the changes that have been observed over the last few years. We show how legal and commercial reforms, made to improve banking integration, could have implications for the behaviour of the consumer in his acts of payment.

In this section we give a brief presentation of this SPA. We primarily show how each payment instrument is used within the various countries of European Union in order to emphasize the differences and the similarities. We also present the main national and European rules on the payment instruments and their impacts on the payment behaviours.

\subsection{The use of payment instruments in the European Union}

Generally speaking, the study shows a reconfiguration of the payment methods use (graphs 1 and 2). In volume, cash and cards replace cheques and credit transfer. In value, use of credit transfer is increasing to the detriment of cheques. The changes are outstanding principally in the Scandinavian countries (Denmark, Finland, and Sweden) because they seem to adopt cashless payment instruments whose support is not paper (electronic transfer, cards) more easily.

However, this general tendency hides a far more complex reality. Indeed the European retail payments market is still split, and payment services vary from one country to another, leading to great differences in structure of payment instruments usage. The Tables 1, 2 and 3 present some statistics on the use of payment instruments in terms of volume and value. These figures show a strong disparity. In volume and in value the dispersion increases for all payment methods except for the cheque. 
To carry out a homogeneous classification of Europe into groups of countries using the same payment instruments is difficult because it varies according to whether one considers the volume or the value. Likewise, this classification depends on the ratios taken as measures of payment instruments use. Taking for example the number of transactions per capita as criterion of classification: There is no denying that, in 2001, Finland, Portugal and Ireland were the countries in which the use of cash was the highest in Europe; Denmark, Finland and the United Kingdom were those where the use of card was most developed; France and the United Kingdom had the greatest frequency of cheque use. The credit transfer was used more intensively in Finland and Sweden and the direct debit in Germany, Austria, and United Kingdom. As we see in Table 2, this classification is modified if we consider the value of transaction per capita as a criterion.

\subsection{National regulations of means of payment}

Institutional environment and banks' trade strategies are possible explanations for the different intensities among countries in the use of means of payment. In this section, we present legal and commercial contexts that are likely to have supported the development of specific payment behaviours in some countries. Countries studied are Finland, France, Germany, Ireland and United Kingdom.

In Finland ${ }^{4}$, despite the high rate of electronification of retail payment methods, the use of cash remains significant with more than 45 annual withdrawals per capita at Automated Teller Machines (ATM), of an average value of 68.5 EUR in 2002. Nevertheless, the number of ATM machines is one of the lowest in Europe; 411 ATMs per 1,000,000 inhabitants, against a European average of 676 per 1,000,000 inhabitants in 2001. The number of ATMs has actually been steadily declining since the early 1990s because of Finland's Great Depression 1990-1993, which led banks to hold down costs by decreasing the number of ATM terminals and charging additional fees when customers were having many cards issued on the same account. This measure encouraged customers to return their ATM cards. In addition to this, banks encouraged retailers to install Electronic Funds Transfers at Point Of Sale terminals (EFTPOS). They also promoted card use by charging fees for each transaction conducted by cheque whereas they were issuing debit cards free of charge. Moreover,

\footnotetext{
${ }^{4}$ For more information about the evolution of retail payments in Finland, see Snellman 2000.
} 
banks implemented customer self-service payments by charging higher fees for overthe-counter transactions. All these measurements led to a high degree of electronification in retail payments methods and to a decrease in cash withdrawals over-the-counter, nevertheless, cash continues to be widely used because of the size of underground economy. According to Paunonen and Jyrkönen (2002), the share of unexplained cash usage in 2000 was about one-half of currency.

France $^{5}$ is the EU country in which the use of cheques is the greatest in volume. In 2001, more than $35 \%$ of non-cash transactions were paid by cheque. Its great usage comes from the existence of a regulated guarantee scheme of payment. Indeed, the increasing number of cheques is a direct consequence of the rule of "nini", i.e. no interest on current accounts and no cheque handling fees. This rule springs from the regulations and the banks' deposit policies whose aim was to raise the level of bank usage and to encourage the opening of savings accounts. Other legal rules also increased customer confidence in using cheques. For example, regulation requires payments by cheque or credit transfer for all transactions whose amount is higher than 1500 Euros. In addition, it is illegal to antedate or to postdate a cheque. Cancellation of a cheque payment is allowed only in the event of loss, robbery, fraudulent use or bankruptcy. Lastly, writing a cheque without cover is an offence which is punished by very heavy legal sanctions. This cheque guarantee scheme has created a favourable legal and commercial environment for cheque use. According to a study conducted in 1999 by the Boston Consulting Group (BCG), banks bear an average cost of 0.75 Euro for each free cheque. Thereby, there is a strong financial equalization between deposit products and credit products. To discourage cheque use, French banks have invested heavily in electronic equipment becoming, after Spain and Denmark, the EU country having the third largest number of EFTPOS terminals per 1,000,000 inhabitants in 2001 . As a result, in 2003 the card became the principal means of payment at POS, displacing the cheque as the dominant payment instrument in terms of the volume of transaction.

Conversely, in Germany ${ }^{6}$ the share of transactions conducted via the cheque is lower than $5 \%$ because there is no regulated guarantee scheme for cheque payment such as that in France. Thereby it is unusual to send cheques by post (eg. the rent to

\footnotetext{
${ }^{5}$ The web site of the monetary and financial French code: http://www.legifrance.gouv.fr/WAspad/UnCode?code=CMONFINL.rcv

${ }^{6} \mathrm{The}$ web site of the regulation of instruments of payment in Germany:

http://www.grundmann-norderstedt.de/gfb4.htm
} 
your landlord). The credit institutions, with the exception of the Bundesbank, do not have the right to guarantee cheques. A debtor can stop an issued cheque at any time before it is presented for payment. These regulations, as well as handling fee charged for cheque transactions, have held down the growth of cheque usage instead of cash. The 1921-1923 hyperinflationary crisis in Weimar Germany is also often cited as a reason to explain the German preference for cash rather than cheques. In addition, because of the high minimum transaction value for credit card payments at POS, Germany has the lowest number of EFTPOS terminals in Europe: 5,291 per 1,000,000 inhabitants against an average European of 11,792 in 2001. Thereby, cash is also preferred over cards for small purchases. This lack of competing payment instruments at POS explains why cash payments are always the most widely used payment method for person-to-person payments.

The United Kingdom and Ireland are countries in which cash and cheque use have increased in the same way. In the United Kingdom, cheques became popular after the mid-1960s with a marked increase in the number of bank account holders and the introduction of cheque guarantee cards. However, with the exception of Lloyds TSB, banks do not cash the cheques free of charge. In Ireland, in like manner, the increase in the number of cheque guarantee cards has facilitated the popularization of cheque use. Neither the government nor the banks have targeted investment towards the electronic payments infrastructure. As a result, cheques and cash have remained the main means of payment at POS. A study undertaken in 1999 by the BCG found that less than one-half of civil servants' wages were paid via automatic transfers. Furthermore, customers use cash to pay $75 \%$ of their water, gas and electricity bills. Three quarters of social security benefits are paid by cash, or bank cheque and only $55 \%$ of Irishmen have a bank account.

\subsection{European regulations for the implementation of the SPA}

Payment behaviours also result from international environments. Various legislative measures adopted by the European Parliament in order to promote EU integration and to achieve the objective of the SPA also influenced payment services providers and consumers:

$>1^{\text {st }}$ July 1990: The beginning of the first stage of EMU whose objectives were the convergence of inflation rate and the reduction of public deficits. The principle of full freedom of capital movements which was a necessary condition to the creation of 
a single market for financial services was incorporated into the Treaty in November 1993. The entry into force of these criteria enhanced the comparability of prices, increased consumer choice and competition and sped up the integration of national payment markets.

$1^{\text {st }}$ January 1994: The start of the second stage of EMU. The Maastricht Treaty on European Union (1992) introduced other arrangements for capital movements, and secured broad convergence between the economic policies. This improvement of the full liberalisation of capital movements and payments is likely to have promoted the development of payment instruments whose cross-border use was cheaper, easier, less time consuming and more reliable.

27 January 1997: Directive 97/5/EC of the European Parliament and of the Council on cross-border credit transfers. This specifies transparency obligations with respect to the method of calculating the commission fees and charges. It also establishes standards regarding the value dates applied and the execution time needed to carry out transfers of less than $€ 50.000$. By facilitating the cross-border transfers, this Credit Transfer Directive (hereafter CTD) encourages customers to use this particular means of payment.

$>1^{\text {st }}$ January 1999: The beginning of the third stage of the EMU, with the irrevocable fixing of the exchange rates, introduction of the single currency (EURO), and the beginning of the TARGET system of payments (Trans-European Automated Real-time Gross settlement Express Transfer). This phase is an important stage for the accomplishment of the SPA because it improves the transparency of financial information and foreign prices as well as the integration of payment systems. A consequence of this may be the increasing influence of foreign supplies on the domestic demand of a means of payment.

19 December 2001: Regulation (EC) 2560/2001 on cross-border payments. This eliminates the differences in price between cross-border and national payments conducted via cash, cards and credit transfers. The regulations became effective in July 2002 for card payments and withdrawals at cash points, and in July 2003 for transfers and electronic purses. This measure does not apply to cheques. It only recommends to banks to include a statement warning on cheque books relating to the cross-border use of cheques. However banks charge high fees for the use of domestic cheques abroad (these costs can reach as high as 40 euros). The non-application of the principle of equal charges to cheques, as well as the withdrawal of the guarantee for 
eurocheques on 1st January 2002, decrease the international use of this payment instrument, though some customers still prefer to pay by cheque because it delays their payments by about 2 to 10 days.

$1^{\text {st }}$ January 2002. The introduction of euro notes and coins. This step is likely to improve the use of cash instead of the other competing payment instrument whose use abroad is not harmonized as yet.

A point that must be emphasised as a result of the regulation on cross-border payments is the resolution of the problem of high fees on bank accounts held by nonresidents. Indeed, additional charges used to be made for bank accounts opened abroad. Some banks, especially in Spain and Austria, were dealing with all the transactions of these accounts as cross-border payments even if they were carried out inside the territory. The measure solves this problem and allows customers to get the best supplies of financial services from foreign banks established abroad without additional fees being incurred simply because the payment crosses a border.

However, these measurements and results are preliminary. Other regulations are needed to ensure price transparency, and to intensify banking competition that will drive down costs. Current regulations relate only to cross-border payments without proposing solutions that will enhance harmonization among jurisdictions. For instance, regarding the revocability or the non-execution of a payment order, national legislatures and banking agreements are widely divergent. In some countries, it is possible to amend or cancel a direct debit or credit transfer instruction after it has been received by the bank, while in others it is illegal to stop a payment order once it has been placed. Thus, in England, customers may post-date a cheque, and the bank does not have the right to cash it earlier than the date inserted on it (if a post-dated cheque is paid before the date on it, customer can ask the bank to refund it). While on the contrary, to post-date a cheque is illegal in France. Likewise, in Germany the debtor can stop a cheque for commercial reasons, whereas it is not the possible in France. In England writing a cheque that bounces incurs a charge for non-payment of the cheque and a charge for being overdrawn on the account, while writing a cheque without funds is illegal in Spain. So, the implementation of new changes is required to improve competition that will allow customers to take full advantage of the SPA. 
Moreover, to be effective, these measurements must be supplemented by the integration of existing inter-bank payment infrastructures between credit institutions.

\section{METHODOLOGY}

\subsection{Data}

We study five payment instruments: cash, cheques, card, credit transfer and direct debit. We do not include the electronic money - that is multipurpose prepaid cards and network/software-based products - because they were not much used during the period of study. We also do not make any distinction between credit card and debit card, and between paper based credit transfer and electronic credit transfer. For each country and for each payment instrument, we use annual data from 1990 to 2001. These data measure the importance of payment instruments use in volume and in value. They are collected from the Blue Book of the European Central Bank (ECB) and from the Red Book of the Bank for International Settlements (BIS). Private consumption and consumer prices index come from the International Financial Statistics, series of December 1997 and 2002.

\subsection{Assumptions}

We assume that the payment instruments do not have any intrinsic value. They are just seen like means of transferring money. Thus, the preference and usage of a payment method depends both on the characteristics of banks supply and on the related regulations. We identified four main features which determine the demand for a payment instrument:

- Price and security: Price includes banking fees and additional products and services such as insurance, bonuses, gifts, etc. Security refers to the potential risk associated with the use of a payment instrument. For instance, by accepting cheque payments, the depositary is exposed to credit risk if the customer does not have sufficient funds in his or her account to cover the returned cheque. For card payments, the potential risks are credit losses due to contractual delinquency and bankruptcy, risks to customers' physical safety at ATM locations, and risks due to fraud losses (which include unauthorized use of lost or stolen cards, fraudulent applications, counterfeit or altered cards). For cash payments, the risk is cash losses resulting from theft or acceptance of counterfeit money. The security is managed and provided by 
banks through insurance contracts whose cost is included in the price. We took interest rate to measure both price and security and we assume that the demand is price elastic.

- The accessibility: That is the transaction time, the speed, reliability and ease of use a means of payment. The quicker the payment service technology, and the more convenient the payment method, the faster the transaction. So, fast and easy-touse payment technology increases customers satisfaction and revenues for retailers by speeding up the checkout line. It therefore generates repeated behaviours. We measure technology for cash payments by the number of ATM terminals. Both number of ATM and EFTPOS terminals measure technology for card payments. For the other payment instruments, there is no data available relating to technological indicators like the number of cheque printing machine at POS, or the number of giro ATM networks.

- Standardization: This depends on the payment interface compatibility and on the harmoniousness of legislations. A standardized payment instrument can be used in the same way across Europe: e.g.: euro currency, international card, eurocheques and so on. However, each EU country has laws that deal with the sale of payment instruments and those laws vary extremely from country to country. Since 1990, the European institutions and the banking industry have attempted to create statutory frameworks that tie together the various types of legislation and banking operating rules (e.g. by providing a uniform and cost-effective manner of the reporting and record-keeping requirements, by creating an International Bank Account Number and so on). The cooperation between payment systems, the sharing and exchange of information reduce the cost of processing and the price of a payment instrument. To measure these phenomena we took variables for the integration of payment systems and for the standardized European legislations.

- Past habits: Empirical studies found that people base much of their decisionmaking on the simple rule of familiarity. They are often buying on the basis of past habits and general familiarity. If simplistic decision-rule is the key element of the process for consumers choosing the payment instrument to use, then this suggests that breaks in usual habitual practices come in a high probability from banks' commercial policies and tends to emphasise the importance of marketing strategies. 
In addition, there are a variety of payment transactions. Each one depends on characteristics such as the distance between debtors and creditors, the frequency of the payment, the confidence in the counterpart. Therefore, there are a great number of payment instruments having properties adapted to a specific kind of transaction. Thus, competition between payment instruments depends at the same time on the type, the place and the amount of the transaction. So, one cannot have a perfect substitution between all the payment instruments and only some are accurately in competition. This is why in our study we will distinguish two groups of payment instruments in which competition can be observed: on the one hand the person-to-person payment instruments which are cash, card, and cheque, and on the other hand the remote payment instruments which are card, cheque, credit transfer and direct debit. Considering these assumptions, we test conditional convergence of European payment behaviours.

\subsection{Variables}

\section{Payment instruments}

It is difficult or even impossible to measure empirically the value and volume of cash payments because there is no data available for cash use at point-of-sale. We therefore used proxy variables. We compute them as follows:

$$
C A S H(v o l) i t=n_{i t} \theta_{i t} \quad \text { and } \quad C A S H(v a l) i t=n_{i t} \psi_{i t} \theta_{i t}
$$

where $n_{i t}$ is the total number of cash withdrawal per inhabitant for the country $i, \psi_{i t}$ is the average real value of transaction by ATM per capita and $\theta_{i t}$ is the velocity of the money. The latter is obtained by dividing the total value of transaction by ATM by the stock of money. We consider only banknotes and coins in circulation outside the credit institutions. Value of cash kept in vaults at deposit-taking institutions is excluded. However, we must emphasise that values and volumes obtained are only approximations because there is a substantial amount of cash, difficult to measure precisely, in circulation outside the country of origin. In addition, statistics provided do not include withdrawals made at banks and post offices.

Because account-based instruments require intermediaries, it is easier to gather data. Use of cashless instruments is measured by the total number/value of cashless transactions per capita. Values are all deflated. These statistics do not take into account the transactions in which the debtor is also the recipient. For instance, 
cheques written by the account holder for himself in order to obtain cash are not included in the number/value of transactions. Postal money orders are included in the credit transfers and traveller's cheques in the cheques.

\section{Macroeconomic indicators:}

- Private consumption per head (CONSUMP). This is defined as total real household consumption expenditure. It is obtained by dividing the nominal private consumption per person by the consumer price index (taking 1990 as the base year). All the series are converted into euros using the annual average exchange rates for the euro provided by ECB.

- Interest rate (INTEREST). We took the nominal average deposit interest rate per year.

Since the integration of EMU economies supposes the nominal convergence of types of interest, we expect the interest rate to speed up the convergence process. In addition, with regard to the demand-for-money theory, interest rates should be negatively correlated with cash holding (Baumol 1952, Tobin 1956, hereafter BM). We also expect a similar result with the private consumption, but the impact may be less strong because the achievement of a real convergence of the standard of living, called by the Commission "economic and social cohesion", will require a much longer timescale. In addition, higher real consumption is supposed to increase cashless transactions (Avery and al 1986).

\section{Technological indicators:}

- Number of ATM (Automated teller Machines) terminals per person (ATM)

- Number of EFTPOS terminals per person (EFTPOS)

These variables measure the availability of the technology and its impact on the use of cash and cards. Unlike GL and HPV, we do not take them as explanatory variables for the other payment instruments. We also do not include some technological indicators for other payment methods such as the number of cheque deposit machines, or the amount of printing equipment because there is no available data. ATM terminals are supposed to increase the relative use of cash by reducing the transaction costs of getting cash. They will thus lead to the decrease of the average cash balance (BM theory), making greater the use of cards for cash withdrawals. So we expect this variable to be positively correlated both with cash and card. On the contrary, EFTPOS terminals are expected to increase cards use rather than cash. 


\section{Indicator of the integration of the payment systems:}

- Financial flows per person (OPENING)

Contrary to other papers studying the demand for payment instruments, we take into account the integration of payment systems by introducing a new variable (OPENING). It is obtained by totalising the messages sent and received by SWIFT (Society for Worldwide Interbank Financial Telecommunication). This indicator is not certainly the best for measuring the financial opening of payment systems, but we chose it because of the availability of the data. A high degree of integration enhances the harmonization of payment systems regulations and may encourage the convergence of payment behaviours.

\section{Indicators of the regulation:}

There is much speculation about what the consequences of these different regulations will be for the payment behaviours and the use of payment instruments. To settle the matter, we chose the three indicators of payment systems regulation which seem to be most important.

- The second step of the SPA (REG94). This corresponds to the start of the second stage of EMU with the entry into force of the Treaty on European Union, and the incorporation into this Treaty of the principle of full freedom of capital movements. To capture the effects of this regulation, we use a dummy variable that takes a value of 0 prior to 1994 and 1 otherwise.

- Directive 97/5/EC on cross-border credit transfers (REG_CTD). The CTD was adopted on 27 January 1997 with a transposition period (30 months) granted for implementing national measures. It came into force on 14 August 1999. It establishes rules on transparency, performance and complaints procedures, so as to ensure that funds can be transferred cross-border from one part of the Community to another rapidly, reliably and at low cost. This regulation is represented by a binary variable which equals 1 for the period 1990-1996, and 0 otherwise.

- The third step of the SPA (REG99). This started on 1st January 1999, with the irrevocable fixing of the exchange rates, the introduction of the single currency, the EURO, and the beginning of the system of payments TARGET (Trans-European Automated Real-time Gross settlement Express Transfer). We also used a dichotomous variable that is zero for Eurozone countries before 1999 and one otherwise. Since Greece's joining occurs after, its variable takes 1 only in 2001. 
All these regulations have prompted the creation of a harmonized common legal environment for payments within the EMU. Therefore, we expect a positive correlation between these variables and the demand for payment methods whose use abroad is faster, cheaper and more reliable. Indeed, REG94 is likely to increase the use of cash, card and, to a lesser extent, credit transfers. In the same way, REG_CTD step up the number of credit transfers by ensuring that they can be processed rapidly, reliably and inexpensively. Likewise, REG99 may enhance cash use by diminishing bank exchange fees, thanks to the disappearance of inter-country exchange risk. It could thus increase card use via cash withdrawals at ATMs abroad.

\section{TEST OF CONVERGENCE}

In this section we carry out tests of conditional $\beta$-convergence and $\sigma$ convergence. These tests are extensions to panel data of the conventional tests of convergence in cross section. First of all, we provide brief overviews of the convergence models, next, we set out the empirical methodology, and finally, we present some summary statistics and the results of the empirical estimations.

\subsection{The concept of convergence ${ }^{7}$}

The problem of convergence has been one of the crucial issues of empirical growth literature for many years. Authors have tried to determine if poor economies can catch up with the per capita income level of richer economies This question was first treated by the neo-classical model of growth of Solow (1956), which showed that countries with identical technological parameters and similar preferences converge towards the same level of income per capita at a stationary state. This concept was then formalized using three different econometrical methodologies.

The first approach was developed by Barro and Sala-i-Martin (1992, 1995), henceforth BS, on cross-sectional data. They consider that there is a convergence, known as the $\beta$-convergence, when the growth rate is negatively correlated with the initial level of the variable. The $\beta$-convergence can be either absolute (or unconditional) or relative (conditional). The former does not take into account the initial conditions of the variables, implicitly supposing a similarity in their parameters (technologies, structure...). In this case, all the countries of the sample studied

\footnotetext{
${ }^{7}$ For a review of the literature on convergence see Fuss Catherine, 1999.
} 
converge towards the same stationary state. Conditional $\beta$-convergence is different from the preceding one because it concerns convergence towards multiple (countryspecific) steady states. Additional variables are added on the right-hand side of the regression to control the heterogeneity of the stationary states. The two tests have different implications; indeed, absolute $\beta$-convergence supposes an equalization of the variables to the same single value in the long term, while the conditional $\beta$ convergence implies that each country converges towards its own stationary state, which can be different from that of the others.

Another convergence model, named $\sigma$-convergence, analyzes the evolution of the dispersion within the sample. The standard deviation is generally used to measure the dispersion. When the dispersion across a group of economies falls over time, there is $\sigma$-convergence. Quah (1993) shows that $\beta$-convergence is a necessary but not a sufficient condition for $\sigma$-convergence. Indeed, if there is a random shock, $\beta$ convergence would just mean that series turn over naturally towards their average (mechanism of correction), while $\sigma$-convergence would show the specific effects of this shock on each series, and maybe an increase in dispersion.

The $\beta$ - convergence tests has been criticized because they may be plagued by Galton's fallacy of regression toward the mean (Quah, 1993) and because they do not take into account the non-stationarity of the series (Bernard and Durlauf 1991). Nevertheless, the model of cross-sectional conditional convergence tests was extended to the dynamic panel data framework yielding better results. Indeed, a panel framework easily handles the aforementioned problems by allowing us to control for unobservable country-specific effects, and to deal with the problem of correlation between the growth rate and the initial level of the variable.

The second approach studies the convergence as a stochastic process (Bernard and Durlauf, 1995). The test is modelled using time-series analytical techniques including co-integration and non-stationarity. There is evidence of convergence if the difference between the variables of two countries is a zero-mean stationary process.

The third approach uses unit root testing procedure on dynamic panel data (Evans and Karras 1996, Gaulier, Hurlin and Jean-Pierre 1999). It consists firstly of testing the convergence hypothesis and then of characterizing the process as absolute or conditional. The major advantage of this model is that it is more appropriate for non-stationary series. Furthermore, it allows countries to have different speeds of convergence. 
In this paper we adopt BS's classical approach to convergence and apply the extension of their model to panel data econometrics (Islam, 1995). We do not use the unit root test model because it controls all country differences by individual constants. Since we want to highlight the importance of the regulation and the financial opening in the evolution of the payments behaviours, and compare it with the one of the technology and the past habits, we add a set of conditioning variables in order to control differences in steady-state level across economies.

\subsection{The model of $\beta$-convergence test in panel data}

Like BS's definition of convergence, we will say that there is convergence if the demand for payment instruments tends towards a common value. So, we make a regression of the growth rate on the initial level.

$$
y_{i, t}-y_{i, t-1}=\alpha+\beta y_{i, t-1}+\varepsilon_{i, t}, \quad i=1, \ldots, 15, \quad t=1, \ldots, 11
$$

$y_{i t}$ is the natural logarithm of the degree of use a payment instrument in country $i$ in year $t . \beta$, the coefficient of convergence, and $\alpha$, the intercept are parameters to be estimated. There will be $\beta$-convergence if $\beta$ is significantly different from zero and negative. The coefficient of convergence is supposed to be the same for all the countries of the panel. We assume that the error term follows a one-way component model:

$$
\varepsilon_{i t}=\mu_{i}+v_{i, t}
$$

where $\mu_{i} \sim \operatorname{IID}\left(0, \sigma_{\mu}^{2}\right)$ and $v_{i, t} \sim \operatorname{IID}\left(0, \sigma_{v}^{2}\right)$ are independent of each other and among themselves. We add lagged values of the dependent variable $\left(\delta y_{i, t}\right)$ as an indicator of the importance of past payment habits. We obtain the equation of the absolute $\beta$-convergence.

$$
\Delta y_{i, t}=\alpha+\beta y_{i, t-1}+\rho \Delta y_{i, t-1}+\mu_{i}+v_{i, t}
$$

To this absolute convergence model, we add two groups of conditioning variables. The first one is composed of the strictly exogenous variables. It includes the macro-economic indicators, the technological variables, the financial opening and the regulations. The second group is made up of the predetermined explanatory variables, which are the demand for competing payment instruments. Indeed, this is a plausible assumption because the use of other payment instruments could have some persistency in determining the current demand for the alternative payment methods. 
The model with control variables added is hence:

$$
\Delta y_{i, t}=\alpha+\beta y_{i, t-1}+\rho \Delta y_{i, t-1}+\gamma X_{i, t}++\eta W_{i, t}+\mu_{i}+v_{i, t}
$$

where $X_{i, t}$ is a $1^{*} k_{1}$ vector of strictly exogenous regressors, that is with $E\left(X_{i, t} \boldsymbol{v}_{i, s}\right)=0$ for all $\mathrm{t}, \mathrm{s}=1, \ldots, 11$.

$W_{i, t}$ a $1 * k_{2}$ vector of predetermined variables. In other words current values of these regressors are correlated with the past errors but are independent of the contemporaneous and future errors. Explicitly, $E\left(X_{i, t} \boldsymbol{v}_{i, s}\right) \neq 0$ for all $\mathrm{s}<\mathrm{t}$ and zero otherwise.

$\gamma$ and $\eta$ are respectively $1 * k_{1}$ and $1 * k_{2}$ vectors of parameters to be estimated. We assume that predetermined and strictly exogenous regressors are all correlated with the fixed effects $\mu_{i}$. All variables are in natural logarithms ${ }^{8}$. Finally we include eleven time dummies variables in the model and we estimate the following dynamic regression model:

$$
\Delta y_{i, t}=\alpha+\beta y_{i, t-1}+\rho \Delta y_{i, t-1}+\gamma X_{i, t}+\eta W_{i, t}+\sum_{j=1}^{11} \xi D_{i, t}+\mu_{i}+v_{i, t}
$$

This dynamic panel data model with fixed effects has two sources of persistence over time: Autocorrelation due to the presence among the regressors of a lagged dependent variable which is correlated with the individual specific effects, and individual effects characterizing the heterogeneity among countries. Autocorrelation makes the OLS estimator biased and inconsistent. The standard fixed effects estimator, also known as Least Squares Dummy Variable (LSDV) estimator, is also not consistent for $\mathrm{N}$ large and finite $\mathrm{T}$. Indeed, notwithstanding the fact that the Within transformation wipes out the $\mu_{i},\left(y_{i, t-1}-\bar{y}_{i,-1)}\right)$ will still be correlated with $\left(v_{i, t}-\bar{v}_{i, t}\right)$ (Nickell 1981). Since T is small (11 years) in our panel, we do not use LSDV estimator. The problem is similar with GLS estimation of the random effects model. A procedure with which to face this difficulty consists firstly of taking firstdifferences transformation of equation (5) in order to eliminate the country-specific fixed effects which are the source of bias; and secondly, of utilizing instrumental variables in order to replace explanatory variables that are correlated with the error term

\footnotetext{
${ }^{8}$ Because of the double-logarithmic form of the model, we can interpret the estimated coefficients as elasticities.
} 


$$
\begin{aligned}
\left(\Delta y_{i, t}-\Delta y_{i, t-1}\right)= & \beta\left(y_{i, t-1}-y_{i, t-2}\right)+\rho\left(\Delta y_{i, t-1}-\Delta y_{i, t-2}\right)+\gamma\left(X_{i, t}-X_{i, t-1}\right) \\
& +\eta\left(W_{i, t}-W_{i, t-1}\right)+\sum_{j=1}^{11} \xi\left(D_{i, t}-D_{i, t-1}\right)+\left(v_{i, t}-v_{i, t-1}\right)
\end{aligned}
$$

We use the Arellano and Bond (1991) generalized method of moments (GMM) estimator. It utilizes instruments whose validity is based on the orthogonality conditions between lagged values of the dependent variable $y_{i t}$ and the errors $v_{i t}{ }^{9}$. For the strictly exogenous variables $X_{i t}$, all past, current, and future values are valid instruments. For predetermined variables, only $X_{i, 1}, \ldots, X_{i, t-2}$ are valid instruments in the first-differenced equation at time $t$. We do not include further lags of the dependent or the predetermined variables as instrument because the GMM estimator may perform poorly in small samples when there are too many over-identification restrictions due to a large instrument matrix. We assume that the lagged variable of a payment instrument demand contains sufficient customers' memories relating to past payment behaviours. This hypothesis helps us to avoid multicolinearity problems among explanatory variables while still maintaining most of the information.

The consistency of the GMM estimator depends on the validity of the instruments that is tested using two model specification tests. The first is a test of a lack of second-order serial correlation among the residuals of the differenced equation. To address this issue, we report the $\mathrm{m}_{2}$ under the null $E\left[\Delta v_{i t} \Delta v_{i t-2}\right]=0$. The second is a test of over-identifying restrictions also referred as the Sargan test. Failure to reject the null hypothesis for both tests means that lagged the values of dependent and independent variables are valid instruments.

We also compute the half-life (or the double-life), i.e. the time necessary for the gap to be cut in half (or to be doubled). We obtained it by the following equation:

$$
\tau^{10}=-\ln (2) / \ln (1+\beta)
$$

\footnotetext{
${ }^{9}$ For instance, $\Delta y_{i, t-2}$ is a valid instrument in (6) because it is highly correlated with $\left(\Delta y_{i, t}-\Delta y_{i, t-1}\right)$ and not correlated with $\left(v_{i, t}-v_{i, t-1}\right)$. Thus, GMM estimator is based on the moment conditions : $\mathrm{E}\left(\Delta \varepsilon_{i t}, \Upsilon_{i s}\right)=0, \mathrm{E}\left(\Delta \varepsilon_{i t}, X_{i s}\right)=0$ and $\mathrm{E}\left(\Delta \varepsilon_{i t}\right)=0, \quad$ for $t=3, \ldots T$ and $\Upsilon=\Delta y_{i, t}-\Delta y_{i, t-1}$

${ }^{10}$ Half-life: If $\mathrm{T}=1$, then $\mathrm{y}_{\mathrm{i} 1}=\mathrm{y}_{\mathrm{i} 0}+\beta \cdot \mathrm{y}_{\mathrm{i} 0}=\mathrm{y}_{\mathrm{i} 0} \cdot(1+\beta)$. If $\mathrm{T}=\mathrm{x}$, then $\mathrm{y}_{\mathrm{ix}}=\mathrm{y}_{\mathrm{i} 0} \cdot(1+\beta)^{\mathrm{x}}$.

By definition, half-life is $y_{\mathrm{ix}}=0,5 \cdot \mathrm{y}_{\mathrm{i} 0}$

$$
\begin{aligned}
& \Rightarrow \quad 0,5 \cdot y_{\mathrm{i} 0}=\mathrm{y}_{\mathrm{i} 0} \cdot(1+\beta)^{\mathrm{x}} \\
& \Rightarrow \quad 0,5=(1+\beta)^{\mathrm{x}} \\
& \Rightarrow \quad \mathrm{x}=-(\ln 2) / \ln (1+\beta)
\end{aligned}
$$
}


The results are shown in table 4. For each instrument, we run the regression using indicators of volume and indicators of value. We obtain convergence when $\beta$ is negative and significant. The smaller the $\beta$, the faster the process of convergence. Time-specific effects are not reported for convenience.

\section{$\underline{4.3 \text { The } \sigma \text {-convergence test }}$}

The test of $\sigma$-convergence studies the evolution of the dispersion of the entire sample. It emphasizes the impact of possible shocks on the movement of convergence. There is convergence if the dispersion decreases over time. Various procedures are used for this test. Simplest is to analyze the behaviour over the time of the standard deviation of the variable. The Graphs 3, 4 and 5 show the results obtained for both the independent and the explanatory variables. Seeing that series for Greece and Luxembourg had too much missing data, we excluded them from the sample.

\section{$\underline{4.4 \text { Tests results and discussion }}$}

For all payment instruments, except cheques, results show evidence of both conditional $\beta$-convergence and $\sigma$-convergence in volume and in value. As predicted, the evolution of the demand for payment instruments follows the European harmonization movement initiated by the creation of the SPA. The divergence in the demand for cheques is due to the fact that the cheque remains primarily a national payment instrument, which is subject to very different legal rules. There is no infrastructure for handling cross-border cheques and charges are still high. This unsuitability of the cheque as an international payment instrument and the heterogeneity of the national rules does not encourage either consumers or banks to imitate and import foreign technologies and behaviours with regards to payments by cheque.

With the exception of credit transfers, the convergence process is faster in value than in volume. It is difficult to find a common explanation for all the countries because legal contexts and administrative obligations differ enormously from one country to another. However, we might think that the convergence in value is faster because the contractual practices and the legal requirements generally relate to the amount of the transaction like the existence of a maximum/minimum amount for 
payments by cash/card, or the transactions fees proportional to the amount for payments conducted via credit transfer.

In a general way, the convergence process is faster for cash than for the other instruments. Indeed, compared to the other payment methods, cash has the highest speed of convergence in value and in volume. This can be explained by the fact that cash payments are more flexible. They have less technological and administrative constraints than the other payment methods. Indeed, the use and the process of all cashless instruments requires a specific technology (EFTPOS, giro ATM, internet connection...) to carry out the payment transactions. These constraints heighten their transaction costs whereas the convenience of cash payments increases their use. Graphs 2 and 3 show that the share of cash payments in the financing of private consumption has increased between 1990 and 2001 more quickly than any of the other instruments. This faster growth of cash use is likely to have involved a higher speed of convergence.

Relating to the substitution between payment methods, results disclose that there is little competition between different payment instruments. We find a two-sided competition only on the one hand between card and cheque in volume and on the other hand between card and credit transfer again in volume. There is a nonreciprocal competition between credit transfers and cheque, suggesting that the decrease of cheque use is mainly caused by credit transfer competition. The competition between card and credit transfers may appear surprising because cards are currently instruments used mainly for face-to-face payments while credit transfers are exclusively used for remote payments. This unexpected result is due to the high level of electronification of retail payments in Scandinavian countries (Sweden, Denmark and especially Finland). In their paper, GL also found a negative relation between card use and cheque demand but significant only in value. Contrary to our results, HPV's study demonstrated competition between all payment methods, except debit cards.

The other results contrast with the prediction of the conventional substitution relation between payment methods. Indeed, our findings reveal a complementarity between on the one hand card and cash and on the other hand credit transfer and direct debit. This lack of competition is owing to the imperfect exchangeability of payment methods. In actual fact, each payment instrument has some features which distinguish 
it from the others. Therefore, it cannot easily be substituted for particular transactions (deposit cheque, cash payments at distributors...).

So, results showing that direct debits do not compete against cheques can be explained by the characteristics of these two instruments. In fact, with the direct debit it is the beneficiary who initiates the funds transfer from the account of the customer to his own account whereas with the credit transfer the payment order is given directly by the debtor to its payment service provider without passing through the beneficiary. Thus the differentiation is owing to the fact that the payment order can be direct or indirect. That is why the two instruments are not perfectly substitutable.

That notwithstanding, the absence of competition between cash and card is unexpected because these payment methods are close substitutes for each other. This result may be justified by the existence of a 'de minimis' threshold for card payments at POS. Indeed, the minimum amount for payments conducted via cards shift the competition above that value and enhances the use of cash for transactions of low value. This may also explain why changes from cash to new instruments, especially electronic payments, have been slower than predicted. However, this elasticity of demand between cash and card, even though positive, is low (0.12). This result is nearly the same as the one found by GL. For the other payment instruments variables, we find insignificant coefficients.

The lagged dependent variable coefficient is used to capture how resistant to change, payment behaviours are. Unlike GL who found a positive impact of the force of habit in volume and in value for all the payment instruments, our results show that habits are significant only for cash use in volume and value, cheque use in volume and direct debit use in value. Additionally, the significant coefficients are relatively low ${ }^{11}$ compared with the value of the other variables. More precisely, a one percent increase (decline) in changes of payment habits eventually leads to a narrowing (widening) in the demand variations of less than 0.16 percent. This reflects a fairly low degree of persistence. Lagged values of changes in demand for each payment instrument contribute little to an explanation of its current value. These findings are in marked contrast to the idea according to which payments behaviours are mainly due to past habits. For each instrument, we find other variables, which have greater

\footnotetext{
${ }^{11}$ Using higher-frequency data, like monthly data, could have increased the importance of dynamics.
} 
elasticities than the force of habit. Our coefficients of the lagged dependent variable are smaller than in the models of GL and HPV presumably because we have added new explanatory variables.

Results also disclose that the financial opening has strengthened the trend of variations in payment behaviours. The payment systems integration variable consistently has a statistically significant coefficient for cash, card and cheque in volume and value, and credit transfer in value. As we expected, the more open a retail market is, the more important the use of payment instruments suitable for crossborder transactions. Effectively, the setting up of bank branches in foreign countries, by increasing among other things international credit business, induces increasing use of international payment methods.

The positive relation between the banking opening up and the demand for cash reflects the decrease of the transaction costs owing to the limited fluctuations of the inflation, interest rates and exchange rates. This stability enhances cash use for international payments. Conversely, the financial opening holds up the demand for cheques because its use abroad is slowed down by its high cost and the absence of homogeneous infrastructures.

Regarding the card, the coefficient of the financial opening variable is significantly positive for the demand variation in value but is negative for demand in volume. This means that the cost per transaction of payments conducted via card abroad is always high but it becomes insignificant when the amount of the transaction is high. More accurately, the integration of payment systems raises the average value of card transactions, and makes them less competitive for low-value transactions (transportation tickets, vending machines or other small cash purchases).

Concerning credit transfers use, the coefficient of the financial opening is significant only for the demand in value and is negative. This result is explained by the high cost of the cross-border credit transfers during the studied period. Effectively, at the end of 2001, the average cost of making a cross-border payment of $€ 100$ via credit transfer was $€ 24^{12}$. In their study, HPV found that the more concentrated the banking systems, the less important the use of paper payment instruments (cheque, paper transfers). Although our institutional variables are different (HPV used a five-

\footnotetext{
${ }^{12}$ This high cost is due primarily to the fact that the Credit Transfers Directive came into operation only in August 1999 and the Cross-Border Payment Regulation in July 2003.
} 
firm concentration ratio, while we work out a ratio starting from the messages exchanged through SWIFT) our results draw similar conclusion: The reduction of the costs of payment transactions in the retail-banking industry by national or international integration leads, de facto, to a decrease in the use of paper-based payment instruments. The clearing of these instruments is more expensive and banks discourage their use both domestically and internationally.

Finally, with regard to direct debit, the financial opening is not significant. It is a fair result because there are neither bank agreements nor regulations, which define the cross-border use of direct debit. Though it is one of the simplest means of payment, it is quite impossible to make a cross-border payment by direct debit chiefly because of the incompatibility of payment systems and domestic legal rules. Therefore, it is plausible that the integration of retail payments markets does not have any impact on the variation of the demand for this means of payment.

Turning our attention to results relating to the indicators of regulation now, it appears that the launching of the single currency in 1999 (REG99) has supported cash use in volume but has slowed down the demand for cheques. We also observe that the second stage of EMU (REG94), which corresponds to the principle of full freedom of capital movements and payments between Member States, has accelerated the decrease in the demand for cheques. The coefficient of this variable for direct debit usage is strongly positive but not necessarily informative, since international direct debit has so far not been available. An unexpected finding is the significantly negative elasticity of the CTD variable with the demand for credit transfers in value. This result may be owing to the very long time of CTD implementation (30 months).

On the whole, results are in line with the hypothesis according to which the enhancement of the cross-border use of a payment instrument accustoms the consumers to its usage both nationally and internationally, and therefore promotes the growth of its total demand. This increase is to the detriment of other means of payment whose use abroad is expensive and less effective.

Looking at the technological variables, results are consistent both with our expectations and with the findings of other studies (HPV, GL, Markose and Loke (2002), Goodhart and al (2001), etc). Indeed, we find a positive relationship between on the one hand the demand for cash and the accessibility of ATM terminals, and on 
the other hand the demand for card and the availability of EFTPOS terminals. ATM terminals appear to be the key factor affecting cash demand before the financial opening. This is not surprising because we have considered that cash withdrawals at ATMs were the principal way of getting cash. In the same way, the increase in the number of EFTPOS terminals encourages card use more in value than in volume. As explained above, this is due to the 'de minimis' threshold which raises the average value of card transactions. These technological variables are excluded from the equation of the other payment instruments in order to avoid potential problems of colinearity.

Concerning the macroeconomic indicators, the coefficient of interest rate is significantly positive for all the payment instruments in value. Taken as a whole, results relating to cashless instruments are in line with the BM's theory according to which interest rate is inversely related to cash holding. Therefore, a rise in interest rate is likely to increase the proportion of cashless payments by reducing cash use. It is difficult to pinpoint the explanations for the coefficients of each noncash payment instrument because we do not have enough data relating to retail banking conditions such as prices, value dates, insurance, and so on. We observe that, from 1990 to 2001, the average annual European interest rate of current deposit lowered from $8.37 \%$ to $3.16 \%$ while the share of cash payments in the private consumption expenditures rose from $1 \%$ to $5 \%$ during the same period. However, the positive relationship between cash demand and interest rate is unexpected. This result may be induced by the relatively low interest rates which have reduced the lost interest earnings from deposit accounts.

The coefficient for the private consumption variable is significant only for the use of credit transfers in volume and is negative. Since it is a suitable payment instrument for regular and recurring payments (rent, water, gas, electric, telephone...), this result suggests that an increase in private consumption, which includes consumer spending and business spending, has obvious implications on the other subsectors of the retail industry. Growth of household final consumption expenditure is primarily used for consumable products and services which are most often paid by cash, card or cheque, such as leisure, travel, entertainment, healthcare and so forth. Unfortunately, coefficients for these means of payment are not significant and cannot be used to give support to this explanation. 


\section{CONCLUSION AND DISCUSSION}

In this study, we undertook an analysis of the dynamic nature of payment behaviours by assessing the impact of the technological innovation, the banking industry integration and the harmonization of regulations on the demand for payment instruments. We uncovered several interesting findings shown in Table 4.

The most significant finding is the new insight provided into studies of payment instrument choice. Indeed, we find that payment behaviours are converging within the EMU. Since customers lack a good understanding of the retail market, the convergence process observed reflects more generally the dynamics of product standardization at a European level. In effect, payment instruments are culturally derived needs which are not considered in the choice of a bank account. Furthermore, banks' fee structures have become increasingly complicated, insomuch as consumers cannot understand them nor compare the infinite variety of contract terms and conditions available in the market. Lastly, transaction costs primarily due to the nonportability of account numbers as well as the switching costs do not encourage customers to change bank just because of more attractive retail payment services. For these reasons, the mobility of customers in the retail market is reduced. Consequently, the convergence of payment behaviours, demonstrated in this study, is resulting from the convergence of the retail banks through standardized products. This standardization process comes both from the intrinsic motivation of providers to take advantage of competitive opportunities arising from increasing banking integration and from regulators' incentives to establish a common legal framework for retail payments. Since regulators and banking industry are stepping up measurements to strip out all existing non-market distortions such as price control, taxes or subsidies on payment services, this result suggests that the dynamics of convergence will increase more and more with the achievement of the SEPA, all the more so with the fall of the influence of cultural differences on payment behaviours.

In essence, some previous empirical studies have led to the conclusion that "payment habits are slow to change". In this paper, we found that changes in payment behaviours can be faster than they usually appear. By including new explanatory variables, which had not been taken into consideration yet, we found other factors than the force of habit, such as the modifications of legislation related to the payment services or the reconfiguration of the retail banking market, that impact considerably 
on the demand for payment instruments. Moreover this, the estimated half-lives indicate that the convergence process is relatively fast, therefore differences in payment cultures will neither slow down the achievement of the SEPA, nor be a step backward for countries with more advanced payment methods standardization.

In the debate between legislator, banking industry and users, which concentrates largely on the role of European regulations and banking agreements in the continuing evolution of retail banking market, it is hoped that this study will provide a realistic assessment and strategic insights on these questions.

\section{REFERENCES}

ARELlANO, Manuel and BOND, Stephen « Some Tests of Specification for Panel Data: Monte Carlo Evidence and an Application to Employment Equations » Review of Economic Studies, vol 58, Issue 2, 1991.

AVERY, Robert B., ELLIEHAUSEN, Gregory E., KENNICKELL, Arthur B. and SPINDT, Paul A. "The use of cash and Transaction Accounts by American Families » Federal Reserve Bulletin, Board of Governors of the Federal Reserve System, February 1986

BANK FOR INTERNATIONAL SETTLEMENTS « Statistics on payment and settlement systems in selected countries » Basle, 1991, 1995, 2002.

BARRO, Robert J. and SALA-I-MARTIN, Xavier « Convergence » The Journal of Political Economy, vol 100, n², pp. 223-251, 1992.

BARRO, Robert J. and SALA-I-MARTIN, Xavier « La croissance économique » McGraw-Hill, Ediscience, 1996.

BAUMOL, William J. «The Transactions Demand for Cash: An inventory Theoretic Approach» The Quarterly Journal of Economics, Vol. 66, Issue 4, November 1952.

BERNARD, Andrew B., and DURLAUF, Steven N. " Convergence in international output » Journal of Applied Econometrics, 10, 1995

BOESCHOTEN, Willem C. "Currency use and payment patterns » Dordrecht, 1992.

EVANS, Paul, and KARRAS, Georgios « Convergence Revisited» Journal of Monetary Economics, n`37, 1996. 
EUROPEAN CENTRAL BANK "Payment systems in the European Union », 1996, 2000, 2003.

FUSS, Catherine «Mesure et test de convergence: une revue de la littérature » Revue de l'OFCE n69, avril 1999.

GAULIER, Guillaume, HURLIN, Christophe, and JEAN-PIERRE, Philippe «Testing Convergence : a panel Data Approach » Annales d'économies et de Statistiques, $n^{\circ} 55-56,1999$

GUARIGLIA, Alessandra, and LOKE Yiing Jia "What determines the value and volume of non-cash transactions? Evidence from a panel of european and North American countries » Applied Economics, vol. 36, no. 4, March 2004.

GOODHART, Charles, and KRUEGER, Malte " The Impact of Technology on Cash Usage » Financial Markets Group, Discussion Paper 374, 2001

HUMPHREY, David B., LAWRENCE, Pulley B. and VESALA, Jukka M. "Cash, Paper, and Electronic Payments: A Cross-Country Analysis » Journal of Money, Credit and Banking, Vol. 28, No. 4, Part 2: Payment Systems Research and Public Policy Risk, Efficiency, and Innovation, November 1996.

ISLAM, Nazrul « Growth Empirics: A Panel Data Approach » Quarterly Journal of Economics, vol 110, Issue 4, 1995

MARKOSE Sheri, and LOKE Jia Yiing «Changing trends in payment systems for selected G10 and EU countries 1990-1998 » University of Essex, Economics Department Working Paper n $508,2000$.

MARKOSE Sheri, and LOKE Jia Yiing «Can cash hold its own? International comparisons: Theory and evidence» University of Essex, Economics Department, April 2002.

NICKELL, Stephen "Biases in dynamic Models with fixed Effects », Econometrica, Vol 49, 1981

PAUNONEN Heli, and HANNA Jyrkönen « Cash usage in Finland - How much can be explained? » Bank of Finland, Discussion Papers 10, 2002

QUAH, Danny « Galton's fallacy and tests of the convergence hypothesis »Centre for Economic Policy Research, Discussion Paper, n820, 1993.

SNELLMAN, Jussi, VESALA, Jukka and HUMPHREY, David «Substitution of noncash payment instruments for cash» Journal of Financial Services Research, 2001

SNELLMAN, Jussi «Evolution of retail payments in Finland in the 1990s » Financial Markets Department, 2000.

TOBIN, James «The interest-elasticity of transactions demand for cash 》 Review of Economics and Statistics, n³8 (3), 1956. 


\section{APPENDIX}

Graph 1 : The financing of the private consumption (Volume)
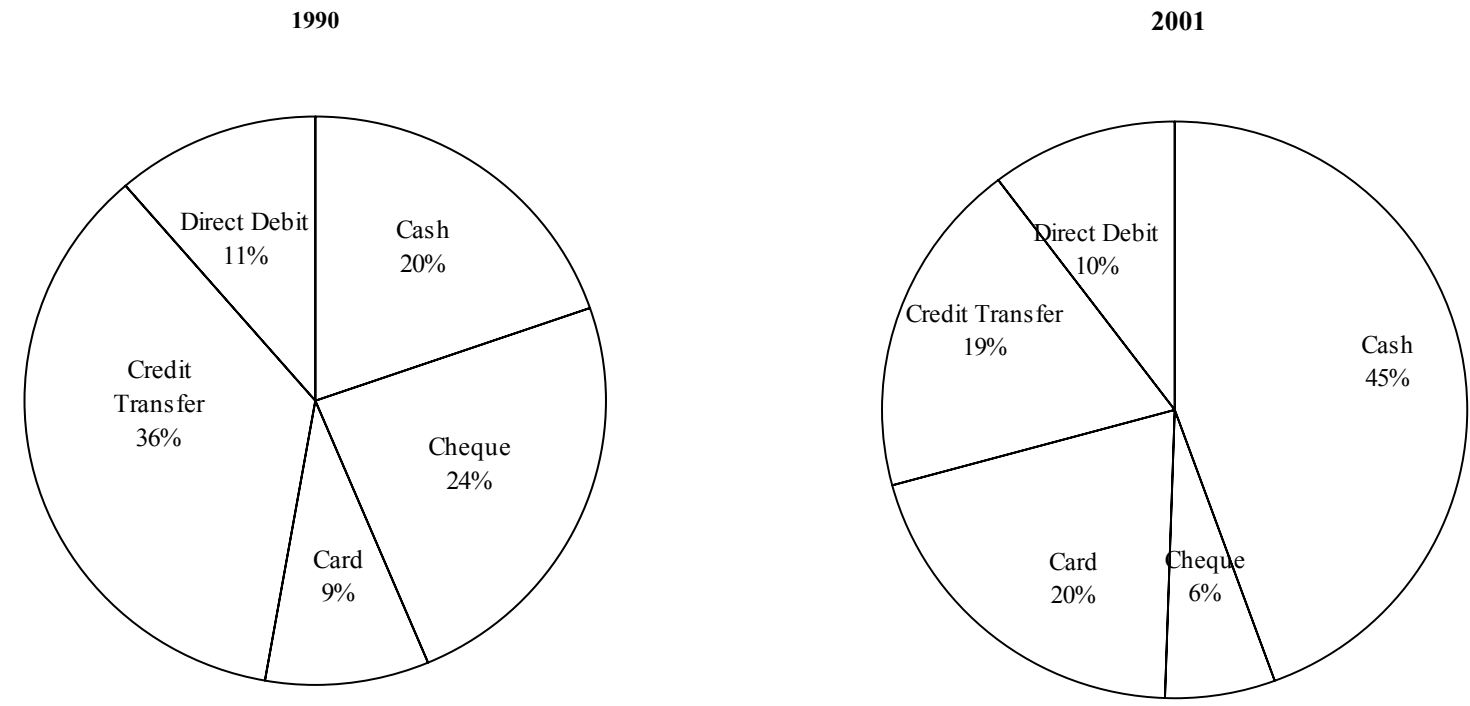

Graph 2 : The financing of the private consumption (Value)
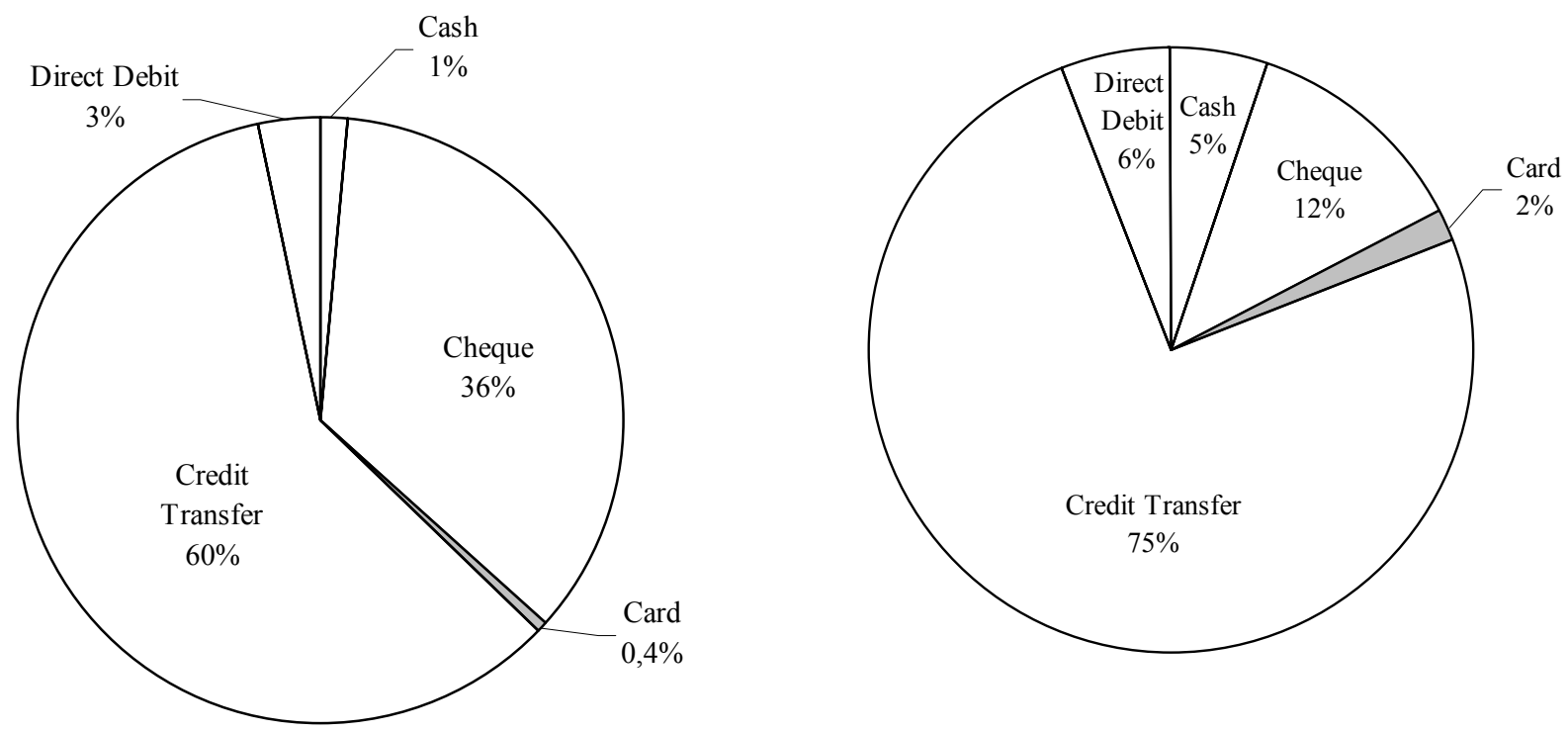


\begin{tabular}{|c|c|c|c|c|c|c|c|c|c|c|}
\hline \multicolumn{10}{|c|}{ Table 1 - Statistics on the use of payment instruments in Europe (volume) } \\
Annual number of transactions per capita \\
\hline & \multicolumn{2}{|c|}{ Cash } & \multicolumn{2}{c|}{ Card } & \multicolumn{2}{c|}{ Cheque } & \multicolumn{1}{c|}{ Credit transfers } & \multicolumn{2}{c|}{ Direct debit } \\
\cline { 2 - 13 } & 1990 & 2001 & 1990 & 2001 & 1990 & 2001 & 1990 & 2001 & 1990 & 2001 \\
\hline Minimum & 0,72 & 15,89 & 0,83 & 4,50 & 2,79 & 0,19 & 1,49 & 4,28 & 0,82 & 6,74 \\
Country & ITA & ITA & ITA & GRE & FIN & FIN & SPA & POR & FIN & ITA \\
\hline Maximum & 124,58 & 325,06 & 39,37 & 87,15 & 85,96 & 71,24 & 70,64 & 97,53 & 37,04 & 56,86 \\
Country & FIN & FIN & FIN & DEN & FRA & FRA & NET & FIN & GER & GER \\
\hline $\mathrm{N}^{\circ}$ Obs & 12 & 14 & 13 & 15 & 12 & 15 & 11 & 14 & 12 & 14 \\
\hline Average & 21,46 & 99,15 & 9,96 & 45,16 & 25,83 & 13,46 & 38,80 & 45,80 & 12,48 & 24,78 \\
\hline Stand. dev. & 34,07 & 83,57 & 10,80 & 25,55 & 23,93 & 19,54 & 24,30 & 30,01 & 10,33 & 16,09 \\
\hline
\end{tabular}

\begin{tabular}{|c|c|c|c|c|c|c|c|c|c|c|}
\hline \multicolumn{1}{|c|}{ Table 2 - Statistics on the use of payment instruments in Europe (value in euros) } \\
Total value of transactions per capita \\
\hline & \multicolumn{2}{|c}{ Cash } & \multicolumn{2}{c|}{ Card } & \multicolumn{2}{c|}{ Cheque } & Credit transfers & \multicolumn{2}{c|}{ Direct debit } \\
\cline { 2 - 14 } & 1990 & 2001 & 1990 & 2001 & 1990 & 2001 & 1990 & 2001 & 1990 & 2001 \\
\hline Minimum & 1.37 & 12.81 & 0.38 & 4.82 & 10.13 & 0.23 & 26.46 & 88.12 & 3.31 & 10.07 \\
Country & ITA & SPA & NET & SPA & NET & NET & SPA & IRE & FIN & LUX \\
\hline Maximum & 98.04 & 180.85 & 19.60 & 37.45 & 1625.28 & 445.03 & 2489.09 & 3740.40 & 163.78 & 384.73 \\
Country & FIN & FIN & FIN & UK & UK & IRE & FIN & BEL & GER & GER \\
\hline $\mathrm{N}^{\circ}$ Obs. & 12 & 14 & 13 & 14 & 12 & 15 & 11 & 15 & 12 & 14 \\
\hline Average & 16.40 & 67.88 & 5.17 & 20.67 & 425.12 & 154.16 & 714.75 & 946.27 & 41.59 & 80.02 \\
\hline Stand. dev. & 26.33 & 48.02 & 5.31 & 10.42 & 439.54 & 130.91 & 661.75 & 936.21 & 41.24 & 90.00 \\
\hline
\end{tabular}

\begin{tabular}{|c|c|c|c|c|c|c|c|c|c|c|}
\hline \multicolumn{11}{|c|}{ Table 3 - Percentage of payment instruments use in 2001} \\
\hline \multirow[t]{2}{*}{ Instruments } & \multicolumn{2}{|c|}{ Cash } & \multicolumn{2}{|c|}{ Card } & \multicolumn{2}{|c|}{\begin{tabular}{c|c} 
Cheque \\
\end{tabular}} & \multicolumn{2}{|c|}{ Credit transfer } & \multicolumn{2}{|c|}{ Direct debit } \\
\hline & Volume & Value & Volume & Value & Volume & Value & Volume & Value & Volume & Value \\
\hline Belgium & $32 \%$ & $1 \%$ & $24 \%$ & $1 \%$ & $3 \%$ & $2 \%$ & $34 \%$ & $95 \%$ & $8 \%$ & $1 \%$ \\
\hline Denmark & & & $54 \%$ & $4 \%$ & $6 \%$ & $19 \%$ & $24 \%$ & $68 \%$ & $16 \%$ & $9 \%$ \\
\hline Germany & $32 \%$ & $9 \%$ & $10 \%$ & $1 \%$ & $2 \%$ & $9 \%$ & $30 \%$ & $42 \%$ & $26 \%$ & $39 \%$ \\
\hline Greece & $87 \%$ & $6 \%$ & $8 \%$ & $0,19 \%$ & $3 \%$ & $17 \%$ & $1 \%$ & $77 \%$ & $1 \%$ & $0,13 \%$ \\
\hline Spain & $29 \%$ & $3 \%$ & $19 \%$ & $1 \%$ & $5 \%$ & $30 \%$ & $11 \%$ & $53 \%$ & $36 \%$ & $13 \%$ \\
\hline France & $19 \%$ & $2 \%$ & $24 \%$ & $2 \%$ & $29 \%$ & $29 \%$ & $14 \%$ & $58 \%$ & $14 \%$ & $9 \%$ \\
\hline Ireland & $67 \%$ & $18 \%$ & $13 \%$ & $2 \%$ & $10 \%$ & $60 \%$ & $4 \%$ & $12 \%$ & $6 \%$ & $9 \%$ \\
\hline Italy & $25 \%$ & $3 \%$ & $20 \%$ & $1 \%$ & $16 \%$ & $19 \%$ & $28 \%$ & $73 \%$ & $11 \%$ & $4 \%$ \\
\hline Luxembourg & $19 \%$ & $3 \%$ & $51 \%$ & $4 \%$ & $1 \%$ & $8 \%$ & $23 \%$ & $84 \%$ & $7 \%$ & $1 \%$ \\
\hline Netherlands & $41 \%$ & $6 \%$ & $19 \%$ & $1 \%$ & $0,10 \%$ & $0,01 \%$ & $23 \%$ & $88 \%$ & $17 \%$ & $5 \%$ \\
\hline Austria & $17 \%$ & $2 \%$ & $12 \%$ & $1 \%$ & $1 \%$ & $2 \%$ & $46 \%$ & $88 \%$ & $24 \%$ & $7 \%$ \\
\hline Portugal & $67 \%$ & $14 \%$ & $19 \%$ & $2 \%$ & $9 \%$ & $43 \%$ & $1 \%$ & $39 \%$ & $4 \%$ & $3 \%$ \\
\hline Finland & $64 \%$ & $6 \%$ & $15 \%$ & $1 \%$ & $0,04 \%$ & $6 \%$ & $19 \%$ & $85 \%$ & $2 \%$ & $1 \%$ \\
\hline Sweden & $44 \%$ & $8 \%$ & $18 \%$ & $3 \%$ & $0,09 \%$ & $0 \%$ & $34 \%$ & $86 \%$ & $4 \%$ & $3 \%$ \\
\hline Unied Kingdom & $44 \%$ & $7 \%$ & $22 \%$ & $3 \%$ & $13 \%$ & $27 \%$ & $10 \%$ & $56 \%$ & $11 \%$ & $8 \%$ \\
\hline
\end{tabular}



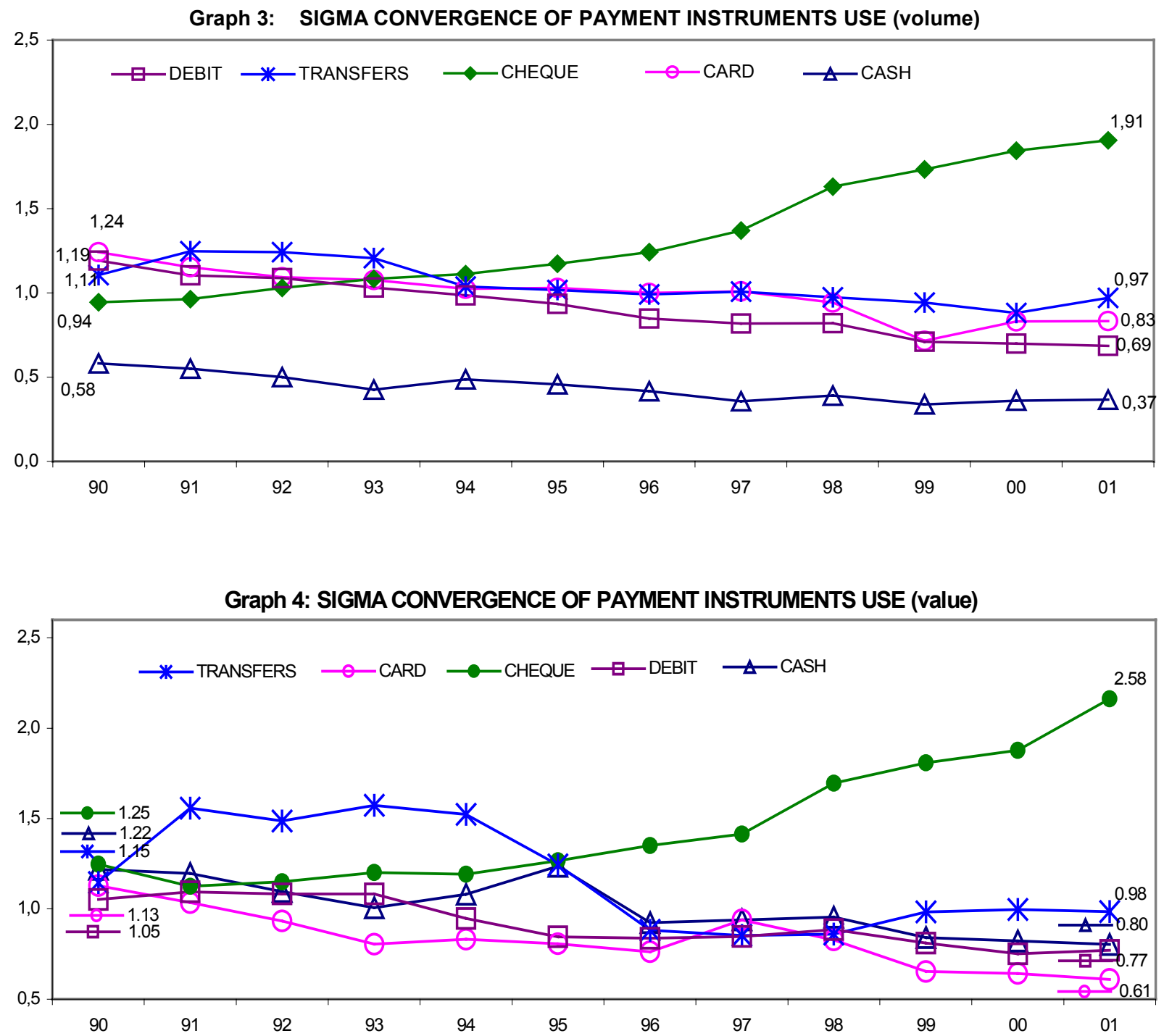

Graph 5 SIGMA CONVERGENCE OF OTHERS VARIABLES

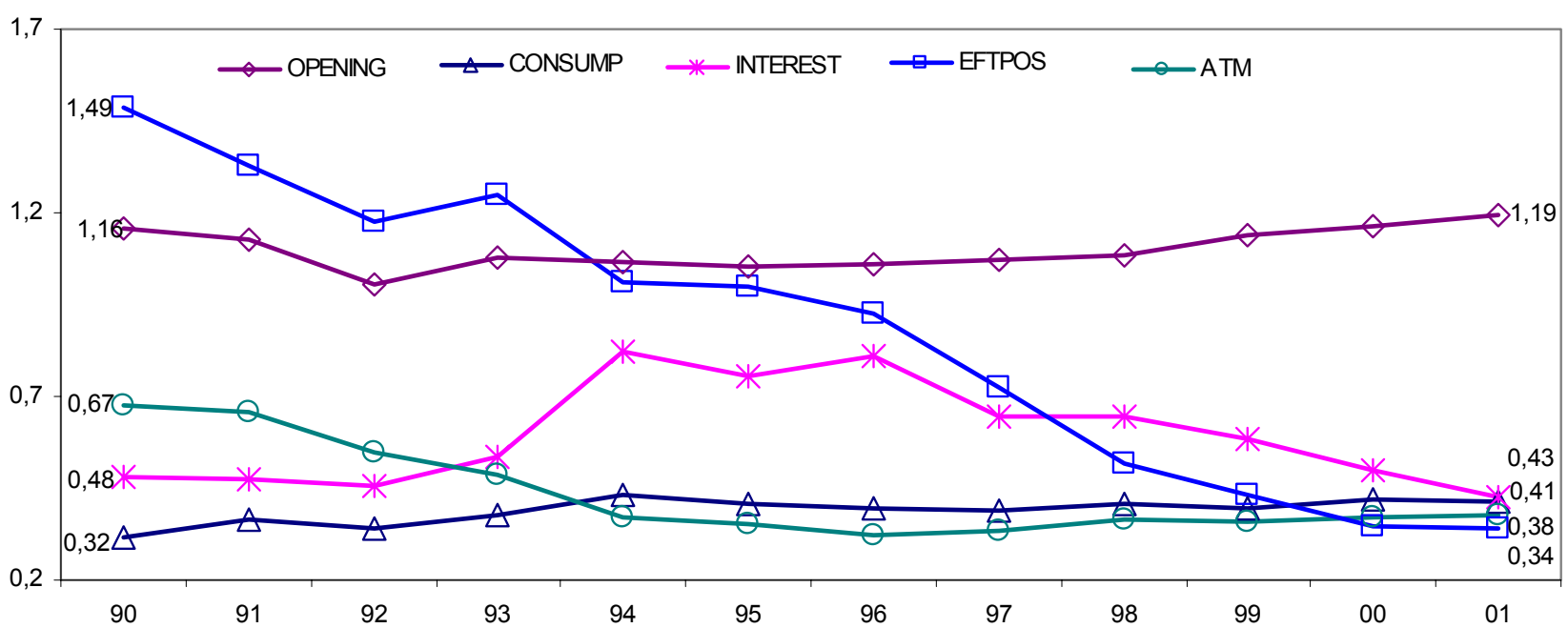


Table 4 - Conditional $\beta$-Convergence

\begin{tabular}{|c|c|c|c|c|c|c|c|c|c|c|}
\hline & \multicolumn{2}{|c|}{$\Delta^{\circ} \mathrm{CASH}$} & \multicolumn{2}{|c|}{$\Delta^{\circ} \mathrm{CARD}$} & \multicolumn{2}{|c|}{$\Delta^{\circ}$ CHEQUE } & \multicolumn{2}{|c|}{$\Delta^{\circ}$ CREDIT TRANSFERS } & \multicolumn{2}{|c|}{$\Delta^{\circ}$ DIRECT DEBIT } \\
\hline & Volume & Value & Volume & Value & Volume & Value & Volume & Value & Volume & Value \\
\hline$\Delta^{\circ} \mathrm{y}_{\mathrm{t}-1}$ & $\begin{array}{l}-0.114^{* * *} \\
0301\end{array}$ & $-0.133^{* * * *}$ & $\begin{array}{l}-0.015 \\
-0.8411\end{array}$ & $\begin{array}{l}-0.033 \\
{[0.6197}\end{array}$ & $-0.155^{* * * *}$ & $\begin{array}{c}0.026 \\
0.7297\end{array}$ & $\begin{array}{c}-0.021 \\
-0.0161\end{array}$ & $\begin{array}{c}0.087 \\
0.2317\end{array}$ & $\begin{array}{c}0.063 \\
04427\end{array}$ & $0.151^{* * *}$ \\
\hline 0 & $\begin{array}{l}-0.541^{* * * k} \\
-10.01\end{array}$ & $-0.600^{* * * * *}$ & $-0.322^{* * * *}$ & $-0.512^{* * * *}$ & -0.011 & -0.274 & $-\mathbf{0 . 3 9 6 * * * *}$ & $-\mathbf{0 . 3 5 3 * * *}$ & $-0.184 * *$ & $\begin{array}{l}-0.593^{* * * *} \\
-10\end{array}$ \\
\hline$\beta$ & {$[0.006]$} & {$[0.004]$} & {$[0.000]$} & {$[0.000]$} & {$[0.782]$} & {$[0.103]$} & {$[0.002]$} & {$[0.000]$} & {$[0.043]$} & {$[0.000]$} \\
\hline Cash & & & 0.047 & $0.124 *$ & 0.058 & $\begin{array}{c}0.021 \\
0.7187\end{array}$ & & & & \\
\hline Card & $\begin{array}{c}0.141 \\
{[0.311]}\end{array}$ & $\begin{array}{c}0.134 \\
{[0.194]}\end{array}$ & & & $-0.221 * * * ;$ & $\begin{array}{l}{[0.115} \\
-0.115 \\
{[0.335]}\end{array}$ & $\begin{array}{l}-0.285^{* * *} \\
{[0.047]}\end{array}$ & $\begin{array}{l}-0.234 * \\
{[0.071}\end{array}$ & $\begin{array}{c}0.003 \\
{[0.959]}\end{array}$ & $\begin{array}{r}0.055 \\
0.0566\end{array}$ \\
\hline Cheque & 0.047 & 0.005 & $-0.073^{* *}$ & $0.204^{* * * *}$ & & & 0.012 & $-0.230^{* * *}$ & $\begin{array}{l}{[.959]} \\
-0.009\end{array}$ & 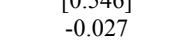 \\
\hline & {$[0.317]$} & {$[0.952]$} & {$[0.025]$} & {$[0.000]$} & & & {$[0.570]$} & {$[0.038]$} & {$[0.742]$} & {$[0.768]$} \\
\hline Transfers & & & $\begin{array}{c}-0.232^{* * * *} \\
{[0.000]}\end{array}$ & $\begin{array}{c}0.045 \\
{[0.242]}\end{array}$ & $\begin{array}{l}-0.017 \\
{[0.728]}\end{array}$ & $\begin{array}{c}-0.034 \\
{[0.307]}\end{array}$ & & & $\begin{array}{c}0.026 \\
{[0.495]}\end{array}$ & $\begin{array}{c}0.127 \\
{[0.105]}\end{array}$ \\
\hline Debit & & & $\begin{array}{c}0.125 \\
\lceil 0.160]\end{array}$ & $\begin{array}{l}-0.041 \\
-0.489]\end{array}$ & $\begin{array}{r}0.012 \\
\lceil 0.859]\end{array}$ & $\begin{array}{r}-0.011 \\
{[0.906}\end{array}$ & $\begin{array}{l}0.125^{*} \\
0.104\end{array}$ & $\begin{array}{l}0.449 * * \\
{[0.027]}\end{array}$ & & \\
\hline Consump & -0.276 & 0.239 & 0.368 & 0.595 & -0.044 & 0.347 & $-0.389^{* * *}$ & -0.729 & -0.137 & -0.164 \\
\hline Consump & {$[0.309]$} & {$[0.469]$} & {$[0.115]$} & [0.131] & {$[0.814]$} & {$[0.142]$} & {$[0.023]$} & {$[0.202]$} & [0.347] & {$[0.683]$} \\
\hline Interest & $\begin{array}{l}0.033 \\
{[0.113]}\end{array}$ & $\begin{array}{l}0.057^{*} \\
0.064]\end{array}$ & $\begin{array}{l}0.008 \\
\lceil 0.3711\end{array}$ & $0.114 * *$ & $\begin{array}{l}0.008 \\
\end{array}$ & $0.066^{*}$ & 0.010 & $0.125^{*}$ & 0.006 & $0.105^{*}$ \\
\hline ATM & $\begin{array}{l}0.470^{* * * *} \\
{[0.007]}\end{array}$ & $\begin{array}{l}0.643^{* * * *} \\
{[0.010]}\end{array}$ & $\begin{array}{c}0.098 \\
{[0.449]}\end{array}$ & $\begin{array}{l}-0.111 \\
{[0.314]}\end{array}$ & & & & & & \\
\hline EFTPOS & & & $0.021 * *$ & $0.341 * * * *$ & & & & & & \\
\hline OPENING & $\begin{array}{l}0.401 * * * \\
{[0.000]}\end{array}$ & $0.483^{*}$ & $-0.183 * *$ & $0.588^{* * * *}$ & $-0.468^{* * * *}$ & $-1.007^{* * *}$ & 0.013 & $-0.594 *$ & -0.039 & -0.510 \\
\hline REG_CTD & & & & & & {$[0.015]$} & $\begin{array}{l}{[0.860]} \\
-0.450 \\
{[0.412]}\end{array}$ & $\begin{array}{l}{[0.070]} \\
-1.131^{*}\end{array}$ & & \\
\hline REG94 & 0.028 & -0.026 & -0.187 & -0.090 & $-0.186^{* *}$ & $-0.123^{*}$ & 0.074 & -0.293 & $0.045^{*}$ & $0.217^{*}$ \\
\hline & {$[0.599]$} & {$[0.677]$} & {$[0.209]$} & {$[0.256]$} & {$[0.053]$} & {$[0.080]$} & {$[0.181]$} & {$[0.186]$} & {$[1.69]$} & {$[0.080]$} \\
\hline REG99 & $\begin{array}{l}0.291 * * * \\
{[0.001]}\end{array}$ & $\begin{array}{c}0.077 \\
{[0.7477}\end{array}$ & -0.007 & -0.000 & $-0.337^{* * *}$ & -0.001 & -0.032 & 0.114 & 0.008 & 0.051 \\
\hline & $-\mathbf{0 . 0 4 3 * *}$ & -0.035 & 0.070 & 0.017 & $0.125^{* * * *}$ & $0.125^{*}$ & 0.061 & $0.241^{* * *}$ & $\begin{array}{c}{[0.802]} \\
0.013\end{array}$ & $\begin{array}{l}{[0.608]} \\
\text { 0.226* }\end{array}$ \\
\hline$\alpha$ & {$[0.024]$} & {$[0.375]$} & {$[0.238]$} & {$[0.827]$} & {$[0.002]$} & {$[0.091]$} & {$[0.360]$} & {$[0.032]$} & {$[0.457]$} & {$[0.059]$} \\
\hline $\mathrm{m}_{2}$ & $\begin{array}{c}-0.49 \\
{[0.626]}\end{array}$ & $\begin{array}{c}-0.36 \\
{[0.721]}\end{array}$ & $\begin{array}{c}0.98 \\
{[0.329]}\end{array}$ & $\begin{array}{c}-1.31 \\
{[0.191]}\end{array}$ & $\begin{array}{c}0.03 \\
{[0.980]}\end{array}$ & $\begin{array}{c}1.75 \\
{[0.080]}\end{array}$ & $-1.50[0.134]$ & $\begin{array}{c}0.39 \\
{[0.694]}\end{array}$ & $\begin{array}{c}0.34 \\
{[0.737]}\end{array}$ & $\begin{array}{c}1.51 \\
{[0.132]}\end{array}$ \\
\hline Sargan test & $\begin{array}{c}\Xi^{2}(176)=84.98 \\
{[1.000]}\end{array}$ & $\Xi^{2}(176)=70.25$ & $\begin{array}{c}\Xi^{2}(264)=87.63 \\
{[1.000]}\end{array}$ & $\begin{array}{c}\Xi^{2}(264)=54.02 \\
{[1.000]}\end{array}$ & $\begin{array}{c}\Xi^{2}(264)=90.84 \\
{[1.000]}\end{array}$ & $\begin{array}{c}\Xi^{2}(264)=68.90 \\
{[1.000]}\end{array}$ & $\begin{array}{c}\Xi^{2}(219)=96.74 \\
{[1.000]}\end{array}$ & $\begin{array}{c}\Xi^{2}(220)=77.05 \\
{[1.000]}\end{array}$ & $\begin{array}{c}\Xi^{2}(220)=104.40 \\
{[1.000]}\end{array}$ & $\begin{array}{c}\Xi^{2}(220)=82.79 \\
{[1.000]}\end{array}$ \\
\hline Wald test & $\begin{array}{c}\Xi^{2}(10)=565.55 \\
{[0.000]}\end{array}$ & $\begin{array}{c}\Xi^{2}(10)=2615.07 \\
{[0.000]}\end{array}$ & $\begin{array}{c}\Xi^{2}(13)=8806.59 \\
{[0.000]}\end{array}$ & $\begin{array}{c}\Xi^{2}(11)=7913.09 \\
{[0.000]}\end{array}$ & $\begin{array}{c}\Xi^{2}(11)=1612.65 \\
{[0.000]}\end{array}$ & $\begin{array}{c}\Xi^{2}(11)=211.59 \\
{[0.000]}\end{array}$ & $\begin{array}{c}\Xi^{2}(12) 69.87 \\
{[0.000]}\end{array}$ & $\begin{array}{c}\Xi^{2}(11) 1933.35 \\
{[0.000]}\end{array}$ & $\begin{array}{c}\Xi^{2}(10)=74.36 \\
{[0.000]}\end{array}$ & $\begin{array}{c}\Xi^{2}(10)=172.57 \\
{[0.000]}\end{array}$ \\
\hline df_m & 19 & 19 & 22 & 22 & 20 & 20 & 20 & 19 & 19 & 19 \\
\hline No of obs & 105 & 86 & 106 & 83 & 104 & 86 & 112 & 95 & 115 & 97 \\
\hline Half-life & 0.89 & 0.76 & 1.78 & 0.97 & - & - & 1.37 & 1.59 & 3.41 & 0.77 \\
\hline
\end{tabular}

$*, * *$ and $* * *$ : significant at the $10 \%, 5 \%$ and $1 \%$ levels . All significant coefficients are shown in bold. The p-values at $5 \%$ level are reported in brackets below the coefficient values.

Time dummies are included in all equations but are not reported in the table. df $\mathrm{m}$ is the model degree of freedom. $\mathrm{m}_{2}$ is the test of second-order autocorrelation in the first-differenced residuals. Sargan statistic is a Chi-squared test of the null that the over-identifying restrictions are valid. Since its asymptotic distribution is not known under the assumptions of the robust model we obtain it by assuming a homoskedastic error term. Wald statistic is a Chi-squared test of the null that all the coefficients except the constant and time dummies are zero. For these two statistics, degrees of freedom are reported in parentheses. Both tests give positive results for all the variables. Half-life is computed as we explained above. 
